\title{
Analisis Penggunaan dana Badan Layanan Umum Daerah (BLUD) Pada Rumah Sakit Umum Daerah Sele Be Solu Kota sorong
}

\author{
Calvin Liawan,SE., M.Sc \\ Akuntansi Keuangan Publik \\ Politeknik Katolik Saint Paul Sorong
}

\begin{abstract}
ABSTRAK
Penelitian ini bertujuan untuk mengetahui penggunaan anggaran pada Rumah Sakit Sele Be Solu Kota Sorong, sebagai kualitas pelayanan kesehatan melalui program Badan Layanan Umum Daerah (BLUD). Kajian ini menitik bertakan pada jenis data kuantitatif dengan metode penelitian pustaka dan penelitian lapangan. Data yang digunakan berupa data sekunder yaitu rincian Kerja Anggaran dan Laporan Realisasi Anggaran. Hasil dari penelitian ini menunjukan bahwa alokasi anggaran memiliki pengaruh yang signifikan terhadap pelayanan kesehatan. Apabila terjadi penambahan pada nilai alokasi anggaran, maka nilai kualitas pelayanan juga akan bertambah.
\end{abstract}

Kata Kunci :Alokasi Anggaran, Kualitas Pelayanan kesehatan, Program Badan Layanan Umum Daerah (BLUD)

\section{PENDAHULUAN}

\subsection{Latar Belakang}

Rumah Sakit adalah institusi kesehatan yang menyelenggarakan pelayanan kesehatan perorangan secara paripurna yang menyediakan pelayanan rawat inap, rawat jalan, dan gawat darurat. Rumah Sakit Pemerintah adalah Rumah Sakit yang dikelola oleh Pemerintah, Pemerintah Daerah dan Badan Hukum yang bersifat nirlaba. Dimana berdasarkan Undang-undang RI. No. 44 Tahun 2009 tentang Rumah Sakit, menjelaskan bahwa rumah sakit mempunyai fungsi yaitu; (1) Penyelenggaraan pelayanan pengobatan dan pemulihan kesehatan sesuai dengan standar pelayanan rumah sakit, (2) Pemeliharaan dan peningkatan kesehatan perorangan melalui pelayanan kesehatan yang paripurna tingkat kedua dan ketiga sesuai kebutuhan medis,(3) Penyelenggaraan pendidikan dan pelatihan sumber daya manusia dalam rangka peningkatan kemampuan dalam pemberian pelayanan kesehatan, (4) Penyelenggaraan penelitian dan pengembangan serta penapisan teknologi bidang kesehatan dalam rangka peningkatan pelayanankesehatan dengan memperhatikan etika ilmu pengetahuan bidang kesehatan. Rumah Sakit Umum Daerah Sele Be Solu Kota Sorong adalah salah satu Rumah sakit yang menerapkan pola pengelolaan keuangan dengan menggunakan badan layanan umum daerah (BLUD), maka profesionalitas serta kualitas pelayanan menjadi konsekuensinya.

Badan Layanan Umum Daerah (BLUD) adalah instansi di lingkungan Pemerintah yang dibentuk untuk memberikan pelayanan kepada masyarakat berupa penyediaan barang dan/atau jasa yang dijual tanpa mengutamakan mencari keuntungan dan dalam melakukan kegiatannya. didasarkan pada prinsip efisiensi dan produktivitas.

Badan Layanan Umum Daerah merupakan bagian dari perangkat pemerintah daerah, yang tidak terpisah dari pemerintah daerah. Pola Pengelolaan Keuangan Badan Layanan Umum Daerah adalah pola pengelolaan keuangan yang memberikan fleksibilitas berupa keleluasaan untuk menerapkan praktek-praktek bisnis yang sehat untuk meningkatkan pelayanan kepada masyarakat dalam rangka memajukan kesejahteraan umum dan mencerdaskan kehidupan bangsa. Praktek bisnis sehat yang dimaksud adalah penyelenggaraan fungsi organisasi berdasarkan kaidah-kaidah manajemen yang baik pada Rumah Sakit dalam rangka pemberian layanan yang bermutu dan berkesinambungan. Dalam pengelolaan keuangan, BLUD diberikan fleksibilitas antara lain berupa: (1) pengelolaan pendapatan dan biaya; (2) 
pengelolaan kas; (3) pengelolaan utang; (4) pengelolaan piutang; (5) pengadaan barang dan/atau jasa; (6) penyusunan akuntansi, pelaporan dan pertanggungjawaban (7) pengelolaan sisa kas di akhir tahun anggaran (8) pengelolaan dana secara langsung.

Adanya keistimewaan yang diberikan kepada BLUD dikarenakan tuntutan untuk meningkatkan kualitas pelayanan dari BLUD. Rencana Bisnis Anggaran (RBA) merupakan perwujudan dari penyusunan anggaran yang disusun oleh BLUD untuk digunakan oleh BLUD itu sendiri. Berbeda dengan unit kerja Pemerintah Daerah lainnya yang menyusun anggarannya dengan menggunakan format Rencana Kerja Anggaran (RKA). Anggaran sektor publik merupakan suatu instrumen perencanaan, pengendalian dan akuntabilitas publik yang ditandai adanya penentuan visi, misi, tujuan, sasaran, dan target organisasi publik serta adanya penetapan indicator kinerja sebagai ukuran kuantitatif yang menggambarkan tingkat pencapaian suatu tujuan yang telah ditetapkan. Anggaran sektor publik merupakan instrument akuntabilitas atas pengelolaan dana publik dan pelaksanaan program-program yang dibiayai dengan uang publik. Sistem anggaran sektor publik dalam perkembangannya telah menjadi instrumen kebijakan multifungsi yang digunakan sebagai alat untuk mencapai tujuan organisasi.

Fungsi anggaran sektor publik sendiri adalah sebagai alat perencana, alat pengendalian, alat kebijakan fiksal, alat politik, alat kordinasi dan komunikasi, alat penilaian kinerja, alat motivasi, dan alat menciptakan ruang publik. Anggaran sektor public bertujuan sebagai alat bagi pemerintah untuk mengarahkan pembagunan sosial-ekonomi, menjamin kesinambungan, dan meningkatkan kualitas hidup masyarakat. Anggaran diperlukan karena adanya kebutuhan dan keinginan masyarakat yang tak terbatas dan terus berkembang, sedangkan sumber daya yang ada terbatas, untuk menyakinkan bahwa pemerintah telah bertanggung jawab terhadap masyarakat.

Anggaran juga membantu seorang pemimpin untuk mengetahui penyimpanan- penyimpanan yang terjadi sehingga dapat dilakukan koreksi-koreksi dan pencegahan dimasa yang akan datang. Anggaran sector publik dibuat untuk membatu memenuhi tinggkat kebutuhan masyarakat pada Rumah Sakit Umum Daerah Sele Be Solu Kota Sorong, dengan bantuan dana BLUD (Badan layanan umum daerah) maka dari itu peneliti ingin mengetahui secara empiris sejauh mana Rumah Sakit menerapkan penggunaan dana/anggaran Badan Layanan Umum Daerah (BLUD) dan pengaruhnya terhadap kinerja keuangan pada RSUD Sele Be Solu Kota Sorong.

\section{TINJAUAN PUSTAKA}

\subsection{Pengertian Akuntansi}

Akuntansi adalah proses pencatatan yang dilakukan untuk menyusun suatu laporan keuangan. Akuntansi biasanya juga disebut sebagai suatu jasa yang didesain untuk membuat laporan keuangan yang dapat dipakai untuk mengambil keputusan pada suatu instansi.

Akuntansi berasal dari kata asing (accounting) yang bila diterjemahkan ke dalam bahasa Indonesia adalah menghitung atau mempertanggung jawabkan.

\subsection{Pengertian Anggaran}

Untuk melaksanakan hak dan kewajiban serta melaksanakan tugas yang dibebankan oleh rakyat,pemerintah harus mempunyai suatu rencana yang matang untuk mencapai suatu tujuan yang dicitacitakan.Rencana tersebut secara matang dan nantinya akan di pakai sebagai pedoman dalam setiap langkah pelaksanaan tugas daerah.dan pada hakekatnya, tugas pemerintah yang penting adalah dalam pengurusan pengurusan keuangan daerah yang mencakup seluruh bidang yang intinya merupakan hak-hak dan kewajibankewajiban pemerintah.

Oleh sebab itu maka rencana-rencana untuk melaksanakan keuangan daerah perlu di buat dan rencana tersebut dituangkan dalam bentuk anggaran.

\subsubsection{Sistem penyusunan anggaran}

Anggaran di susun dengan berbagai sistem-sistem yang mempengaruhi oleh pikiran-pikiran yang melandasi pendekatan-pendekatan tersebut, adapun 
sistem-sistem dalam penyusunan anggaran yang sering digunakan ialah :

a. Traditional budget system ( Sistem anggaran tradisional )

b. Perfomance budget system (Anggaran berbasis kinerja)

c. Planing programming budget system (PPBS)

\subsubsection{Klasifikasi Anggaran}

Anggaran di Indonesia,di

klasifikasikan menjadi beberapa macam dengantujuanuntukmempermudahpenyusu nan, pelaksanaan, dan pengawasannya. Ada beberapa tujuan dari klasifikasi itu yaitu :

a. Klasifikasi Organik

b. Klasifikasi Obyek

c. Klasifikasi Fungsional

d. Klasifikasi Ekonomis

e. Klasifikasi Perfomance

f. Klasifikasi Program

\subsubsection{Siklus Anggaran Negara}

Setelah membahas mengenai pengertian anggaran, sistem anggaran dan klasifikasi anggaran berikut ini akan dibahas mengenai tahap-tahap di dalam anggaran atau lebih dikenal sebagai "Siklus Anggaran".

Pengertian dari siklus anggaran adalah masa atau jangka waktu mulai saat anggaran di susun sampai dengan saat perhitungan anggaran disahkan dengan undang-undang, Siklus Anggaran berbeda dengan tahun anggaran. Tahun anggaran adalah masa 1 (satu) tahun untuk mempertanggung jawabkan pelaksanaan anggaran itu atau waktu dimana anggaran tersebut akan dipertanggungjawabkan". Jelas disini bahwa siklus anggaran bisa mencakup tahun anggaran dan waktunya lebih lama dari tahun anggaran.

Di atas telah diuraikan bahwa siklus anggaran merupakan tahap-tahap anggaran, dengan demikian siklus anggaran terdiri dari beberapa tahap yaitu sebagai berikut :

2.2.3.1 Tahap Penyusunan Anggaran

2.2.3.2 Tahap Pengesahan Anggaran

2.2.3.3 Tahap Pelaksanaan Anggaran

2.2.3.4 Tahap Pengawasan Pelaksanaan Anggaran

2.2.3.5 Tahap pertanggung Jawaban

\section{Anggaran}

\subsection{Pengertian Dana}

Pada awal timbulnya akuntansi dana yang di bentuk oleh organisasi non profit (organisasi nirlaba), dana mempunyai arti dana kas, namun sekarang dana mempunyai pengertian luas yaitu merupakan kesatuan fiscal dan kesatuan akuntansi yang terpisah.

\subsubsection{Macam-macam Dana}

Terdapat 2 (dua) jenis dana yang biasa di gunakan oleh suatu organisasi non profit yaitu :

a) Dana belanja

Dana digunakan untuk membukukan aktiva lancer, hutang dan perubahan dalam aktiva bersih yang di belanjakan untuk kegiatan organisasi nonprofit

b) Dana bukan belanja

Dana ini digunakan untuk membukukan pendapatan, biaya, aktiva, hutang, dan modal kegiatan perisahaan komersial.

\subsubsection{Jenis-jenis Dana}

Setiap kelompok dana memiliki berbagai jenis dana dengan sifat yang sama, kecuali dana kepercayaan yang memiliki sifat belanja dan non belanja. Jenis-jenis dana yang dapat di gunakan di atur dalam prinsip akuntansi dana yang dapat di bagi menjadi 3 (tiga) bagian yakni.

\section{Dana Pemerintah}

a. Dana Umum yaitu dana untuk mempertanggunjawabkan sumbersumber yang tidak di pertanggung jawabkan dalam dana lain

b. Dana pendapatan Khusus yaitu dana untuk mempertanggung jawabkan penerimaan sumbersumber tertentu yang di tujukan untuk aktivitas tertentu

c. Dana proyek Modal yaitu dana untuk mempertanggung jawabkan sumber-sumber yang di gunakan untuk tujuan pemerolehan atau pembangunan fasilitas modal 
d. Dana pelunasan Hutang yaitu dana untuk mempertanggung jawabkan pengakumulasian sumber-sumber untuk membayar pokok dan bunga utang jangja panjang umum.

\section{Dana Kepemilikan}

Dana Perusahaan yaitu dana untuk Mempertanggung jawabkan aktivitas bisnis yang di lakuan oleh pemerintah

\section{Dana Layanan Internal}

Dana Layanan Internal yaitu dana untuk mempertangung jawabkan barang dan jasa yang di sediakan oleh suatu unit pemerintah itu sendiri atau kepada unit pemerintah yang lain

4. Dana kepercayaan

a. Kepercayaan (Trust) yaitu dana yang mempertanggung jawabkan aktiva milik pihak yang di kelolah pemerintah sebagai pihak yang dipercaya.

b. Dana Paragenan yaitu dana untuk mempertanggung jawabkan aktiva milik pihakyang lain yang di kelolah oleh pemerintah yang bertindak sebagai agent.

\subsection{Badan Layanan Umum Daerah (BLUD)}

\subsubsection{Pengertan Badan Layanan Umum} Daerah (BLUD)

Badan Layanan Umum Daerah yang selanjutnya disingkat BLUD adalah Satuan Kerja Perangkat Daerah atau Unit Kerja pada Satuan Kerja Perangkat Daerah di lingkungan pemerintah daerah yang dibentuk untuk memberikan pelayanan kepada masyarakat berupa penyediaan barang dan/atau jasa yang dijual tanpa mengutamakan mencari keuntungan,dan daliam melakukan kegiatannya didasarkan pada prinsip efisiensi dan produktivitas

\subsubsection{Tujuan dan Asas Badan Layanan Umum Daerah PPK-BLUD meningkatkan kualitas pelayanan}

kepada masyarakat untuk mewujudkan penyelenggaraan tugas-tugas pemerintah dan/atau pemerintah daerah dalam memajukan kesejahteraan umum dan mencerdaskan kehidupan bangsa.

\subsubsection{Pola Pengelolaan BLUD}

Pola Pengelolaan Keuangan BLUD, yang selanjutnya disingkat PPK-BLUD adalah pola pengelolaan keuangan yang memberikan fleksibilitas atau kebebasan berupa keleluasaan untuk menerapkan praktek-praktek bisnis yang sehat untuk meningkatkan pelayanan kepada masyarakat dalam rangka memajukan kesejahteraan umum dan mencerdaskan kehidupan bangsa, sepagai pengecualian dari ketentuan pengelolaan keuangan daerah pada umumnya.

Berdasarkan Peraturan Menteri Dalam Negeri Nomor 61 tahun 2007 tentang Pedoman Teknis Pengelolaan Keuangan BLUD, pengelolaan keuangan Badan Layanan Umum terdiri atas:

1.Perencanaan dan Penganggaran

2.Pelaksanaan Anggaran

3. Akuntansi, Pelaporan, dan

Pertanggung Jawaban.

\subsubsection{Manfaat Menjadi PPK-BLUD}

Satuan Kerja Perangkat Daerah yang dibentuk untuk memberikan pelayanan kepada masyarakat berpotensi untuk mendapatkan imbalan secara signifikan terkait dengan pelayanan yang diberikan, maupun dari Anggaran Pendapatan Belanja Daerah (APBD). Satuan kerja yang memperoleh pendapatan dari layanan kepada publik secara signifikan dapat diberikan keleluasaan dalam mengelola sumber daya untuk meningkatkan pelayanan yang diberikan. Hal ini merupakan upaya peng-agenan aktivitas yang tidak harus dilakukan oleh lembaga birokrasi umum, tetapi oleh instansi pemerintah daerah yang dikelola secara bisnis, sehingga pemberian layanan kepada masyarakat menjadi lebih efisien dan efektif yaitu dengan menerapkan Pola Pengelolaan Keuangan Badan Layanan Umum Daerah (BLUD). 


\section{Satuan Kerja Perangkat Daerah yang menerapkan PolaPengelolaan Keuangan BLUD mempunyai manfaat sebagai berikut :}

1. Dapat di lakukan peningkatan pelayanan instasi pemerintah daerah kepada masyarakat dalam rangka memajukan kesejahteraan umum dan mencerdaskan kehidupan bangsa.

2. Instasi pemerintah daerah dapat memperoleh fleksibilitas dalam pengelolaan keuangan berdasarkan prinsip ekonomi dan produktivitas dengan menerapkan praktek bisnis yang sehat.

3. Dapat dilakukan pengamanan atas aset Negara yang dikelola oleh instansi terkait

\subsection{Sistem Akuntansi Instansi (SAI)}

Sistem Akuntansi Instansi (SAI) digunakan untuk menghasilkan pelaporan posisi keuangan dan operasi keuangan pada KementrianNegara/Lembaga.Setiap kementrianNegara/Lembagawajibmenyelen ggarakanSAI untuk menghasilkan laporan keuangan.

SAI terdiri dari :

1. Sistem Akuntansi Keuangan (SAK)

2. Sistem Informasi Manajemen dan Akuntansi Barang milik Negara (SIMAK-BMN).

3. Sistem Akuntansi tingkat unit Akuntasi Pengguna Barang (SA-UAPB).

\subsection{Komponen - Komponen Laporan Keuangan}

Komponen-Komponen yang terdapat di suatu set laporan pokok yaitu

\subsubsection{Laporan Realisasi Anggaran (LRA)}

LRA merupakan salah satu komponen laporan keuangan pemerintah yang menyajikan informasi tentang realisasi dan anggaran entitas pelaporan secara tersanding untuk suatu periode tertentu.

\subsubsection{Neraca}

Neraca adalah komponen laporan keuangan yang menggambarkan posisi keuangan suatu entitas pelaporan pada tanggal tertentu. Posisi keuangan adalah posisi asset, kewajiban, dan ekuintas pada tanggal tertentu.

\subsubsection{Laporan Arus Kas}

Laporan yang menyajikan informasi mengenai penerimaan dan pengeluaraan kas. Penerimaan dan pengeluaraan kas dalam Laporan Arus Kas disajikan berdasarkan aktivitas tersebut. Aktivitas tersebut terdiri atas aktivitas operasi, investasi, aktivitas pendanaan, dan transitoris.

\subsubsection{Catatan atas Laporan Keuangan (CALK)}

Bentuk laporan keuangan yang paling tidak terstruktur, namun harus di sajikan dengan baik, terutama pada penjelasan per pos laporan keuangan harus sesuai dengan tata urutan pos-pos tersebut dalam menyajikan laporan keuangan.

\section{METOBE PENELITIAN}

\subsection{Jenis Penelitian}

Penelitian yang dilakukan penulis adalah penelitian yang berbentuk deskriptif, yaitu penelitian yang menguraikan sifat-sifat dan keadaan sebenarnya dari suatu objek penelitian. Tujuannya adalah mengumpulkan fakta dan menguraikannya secara menyeluruh dan teliti sesuai dengan persoalan yang akan dipecahkan.

\subsection{Jenis dan Sumber Data}

Jenis data yang dikumpulkan berupa data yang bersifat kualitatif dan kuantitatif yang terdiri dari data primer dan data sekunder, yaitu :

1. Data kualitatif merupakan serangkaian informasi yang berasal dari hasil penelitian berupa fakta-fakta verbal dari keterangan seperti sejarah perusahaan, struktur organisasi, dan bidang-bidang kerja.

2. Data kuantitatif merupakan data berbentuk angka-angka baik secara langsung dari hasil penelitian maupun hasil pengolahan data kualitatif menjadi data kuantitatif dengan menggunakan skala interval, seperti 
laporan keuangan perusahaan. Jenis data yang digunakan dalam penelitian ini data sekunder yang bersifat kualitatif dan kuantitatif.

Data-data yang digunakan dalam penelitian ini bersumber dari data yang diterbitkan oleh RSUD Sele Be Solu Kota Sorong melalui media internet. Selain itu data juga diperoleh dari artikel, bukubuku dan dokumen yang berhubungan dengan penelitian seperti struktur organisasi perusahaan, laporan keuangan dan daftar aktiva tetap.

\subsection{Metode Pengumpulan Data}

Didalam usaha untuk mendapatkan dan mengumpulkan data dalam rangka menyusun skripsi ini, penulis melakukan berbagai macam riset.

Adapun riset-riset yang dilakukan adalah :

a. Penelitian Kepustakaan (Library

Reseach)

Merupakan penelitian yang dilakukan dengan membaca dan mempelajari buku-buku serta literatur-literatur yang berhubungan dengan pembahasan masalah.

b. Penelitian Lapangan ( Field Reseach) Merupakan penelitian yang dilakukan dengan cara mengunjungi secara langsung dengan pihak-pihak yang terlibat secara langsung maupun tidak langsung dengan permasalahan.

\section{1) Wawancara}

Untuk memperoleh data yang lebih jelas dan informasi yang benar,dilakukan wawancara langsung dengan pihak-pihak yang terlibat secara langsung maupun tidak langsung dengan permasalahan.

\section{2) Pengamatan (Observasi)}

Suatu cara penelitian dengan mengadakan peninjauan langsung keperusahaan untuk memperoleh data dan informasi yang lebih meyakinkan dalam menyusun skripsi.

\subsection{Teknik Analisis}

Teknik Analisis yang dilakukan dalam penelitian ini adalah teknis analisis dengan menggunakan Laporan keuangan Dana Badan Layanan Umum Daerah (BLUD) pada RSUD Sele Be Solu dan

\begin{abstract}
Buku Pedoman Teknis Pengelolaan Badan Layanan Umum Daerah Berdasarkan Peraturan Menteri dalam Negeri Nomor 61 Tahun 2007

Berikut ini merupakan Contoh penggunaan Dana Badan Layanan Umum Dearah dalam membuat Perencananaan, Realisasi dan Pelaporan Penggunaan Keuangan periode Berdasarkan Peraturan Menteri dalam Negeri Nomor 61 Tahun 2007 tentang Pedoman Teknis Pengelolaan Badan Layanan Umum Daerah.
\end{abstract}

\section{HASIL DAN PEMBAHASAN}

RSUD Sele Be Solu Kota Sorong dalam melaksanakan fungsi dan tugas pengelolaan keuangan Rencana bisnis anggaran yang ditetapkan oleh Peraturan Menteri Dalam Negeri Nomor : 61 Tahun 2007

Pada bagian keuangan Rumah sakit Sele Be Solu Kota Sorong mempunyai sistem dan prosedur Badan Layanan Umum Daerah dalam pengelolaan keuangan Rumah sakit.berikut ini merupakan penyajian data dari tahun anggaran tahun 2015-2016 sebagai berikut.

\subsection{Penyajian Data Rencana Bisnis Anggaran Badan Layanan Umum Daerah}

Jenis dan bentuk sumber penerimaan dana anggaran badan layanan umum daerah pada RSUD Sele Be Solu Kota Sorong yakni penerimaan yang bersumber dari :

\section{a. Jasa Layanan}

Pendapatan yang bersumber dari jasa layanan berupa imbalanyang di peroleh dari jasa layanan yang diberikan kepada masyarakat dalam hal ini Fasilitas Ruangan Rumah Sakit. 
Tabel 4.1

Jumlah Tempat Tidur RSUD Sele Be Solu Kota Sorong

\begin{tabular}{|c|l|c|c|c|c|c|c|}
\hline \multirow{2}{*}{ No } & \multirow{3}{*}{ RUANGAN } & \multicolumn{5}{|c|}{ KELASKEPERAWATAN } & \multirow{2}{*}{ JUMLAH } \\
\cline { 3 - 6 } & & \multirow{2}{*}{ VIP } & \multicolumn{3}{|c|}{ KELAS } & NO & \multirow{2}{*}{ KATEGORI } \\
\cline { 3 - 6 } & & & I & II & III & \\
\hline 1 & Agrek & - & - & - & 32 & - & 32 \\
\hline 2 & BedahI & - & - & - & 12 & - & 12 \\
\hline 3 & Bedah II & - & 2 & - & 8 & - & 10 \\
\hline 4 & Anak & - & 5 & 2 & 17 & - & 24 \\
\hline 5 & Hansen & - & - & - & 10 & - & 10 \\
\hline 6 & VIP/KLS & 2 & 3 & - & - & - & 5 \\
\hline 7 & ICU & - & - & - & - & 4 & 4 \\
\hline 8 & VK: & - & - & - & - & - & - \\
\hline 9 & Obgin & - & 5 & - & 8 & - & 13 \\
\hline 10 & Gynetologi & - & - & - & 5 & - & 5 \\
\hline 12 & Peny. Dalam & - & 5 & - & - & 4 & 9 \\
\hline 13 & Kamar Bersalin & - & 11 & 5 & 5 & - & 21 \\
\hline 14 & Parinatelogi & - & - & 2 & - & - & 2 \\
\hline & JUMLAH & $\mathbf{2}$ & $\mathbf{3 1}$ & $\mathbf{9}$ & $\mathbf{9 7}$ & $\mathbf{8}$ & $\mathbf{1 4 7}$ \\
\hline
\end{tabular}

Sumber : RSUD Sele Be Solu Kota Sorong

\section{b. Hibah}

Pendapatan yang bersumber dari hibah dapat berupa hibah terikat dan hibah tidak terikat.

c. Hasil Kerja Sama dengan Pihak Lain Pendapatan yang bersumber dari hasil kerja sama dapat berupa perolehan dari kerja sama operasional, sewa menyewa dan usaha lainya yang mendukung tugas dan fungsi BLUD.

\section{d. APBD}

Pendapatan yang bersumber dari APBD berupa pendapatan yang berasal dari otoritas kredit anggaran pemerintah daerah bukan dari kegiatan pembiayaan APBD.

\section{e. Lain-lain Pendapatan BLUD}

Lain-lain pendapatan BLUD yang sah antara lain :

1. Hasil penjualan kekayaan yang tidak dipisahkan;

2. Hasil pemanfaatan kekayaan;

3. pendapatan bunga;

4. komisi, potongan ataupun bentuk lain sebagai akibat dari penjualan dan/atau

5. pengadaan barang dan/atau jasa oleh BLUD;

6. hasil investasi.

Seluruh pendapatan BLUD di atas dapat dikelola langsung dalam membiayai kebutuhan Rumah Sakit sesuai rencana bisnis anggaran/RBA pada tahun anggaran.

Jenis dan bentuk pembiayaan Badan Layanan Umum Daerah pada Rumah Sakit Sele Be Solu Kota Sorong antara lain yang terdiri dari.

\section{Biaya Operasional dan Biaya Non Operasional}

a. Biaya Operasional mencangkup seluruh biaya yang menjadi beban BLUD dalam rangka menjalangkan tugas dan fungsinya.

Biaya Operasional itu sendiri terdiri dari

1. Biaya Pelayanan

Biaya Pelayanan mencakup seluruh Biaya operasional yang berhubungan lansung dengan kegiatan pelayanan antara lain :
(a) Biaya pegawai,
(b) biaya bahan,
(c) biaya jasa pelayanan,
(d) biaya pemeliharaan,
(e) biaya barang atau jasa dan
(f) biaya pelayanan lain-lain.

2. Biaya Umum Atministrasi

Biaya Umum Atsministrasi mencakup seluruh biaya opearsional yang tidak berhubungan lansung dengan kegiatan pelayanan antara lain :
(a) Biaya pegawai,
(b) biaya atministrasi kantor,
(c) baiya pemeliharaan,
(d) biaya barang dan jasa,
(e) biaya promosi,
(f) biaya umum dan atminstrasi lain-lain

b. Biaya Non Operasioanal mencakup seluruh biaya yang menjadi beban BLUD dalam rangka menunjang pelaksanaan tugas dan fungsi. Sumber pada biaya non operasional antara lain
(a) Biaya bunga
(b) Biaya atministrasi kantor
(c) Biaya kerugian penjualan aset tetap
(d) Biaya kerugian penurunan nilai
(e) Biaya non operasional lain-lain

Seluruh pengeluaraan Biaya Badan layanan umum daerah akan di sampaikan kepada PPKD setiap triwulannya sehinggah dapat di ketahui tingkat 
fleksibitas atau tingkat penggunaan dana dalam satu tahun anggaran

Data di atas merupakan sumber dari Pendapatan dan pembiayaan/pengeluaraan dana anggaran dalam RBA tahun anggaran Menurut Pemendagri no 61 tahun 2007.

\subsection{Rincian sumber pendapatan anggaran Badan Layanan Umum Daerah}

Berdasarkan penelitian yang dilakukan, diperoleh dari keterangan bahwa rencana bisnis anggaran pendapatan BLUD tahun 2016 diproyeksi sebesar Rp. 1.600.508.000yang terdiri dari realisasi sampai dengan triwulan lalu sebesar Rp.678.088.000dan jumlah realisasi triwulan ini sebesar $\mathrm{Rp}$. 922.500 .000

Berikut ini merupakan Tabel Perencanaan Anggaran BLUD RSUD Sele Be Solu Kota Sorong

Tabel 4.2

Rincian Anggaran Penerimaan Pendapatan RSUD Sele Be Solu KotaSorong Tahun 2016

\begin{tabular}{|c|c|c|c|c|}
\hline No & URALAN & $\begin{array}{l}\text { ANGGARAN DALAM } \\
\text { DPA }\end{array}$ & $\begin{array}{l}\text { REALISASISD } \\
\text { TRIVULAN LALU }\end{array}$ & $\begin{array}{l}\text { REALISASI } \\
\text { TRIVULAN INI }\end{array}$ \\
\hline 1 & 2 & 3 & 4 & 5 \\
\hline & Jasa Layanan & & & \\
\hline & 1 Administrasi Pendaftaran & $70.000 .000,00$ & $45.000 .000,00$ & $60.000 .000,00$ \\
\hline & \begin{tabular}{l|l}
2 & Tindakan Operasi \\
\end{tabular} & $100.500 .000,00$ & $63.500 .000,00$ & $35.000,000,00$ \\
\hline & \begin{tabular}{|l|l|}
3 & Rawat Jalan \\
\end{tabular} & $50.300 .000,00$ & $25.500 .000,00$ & $15.500 .000,00$ \\
\hline & \begin{tabular}{l|l}
4 & Rawat Inap unum \\
\end{tabular} & $150.000,000,00$ & $50.000 .000,00$ & $150.000 .000,00$ \\
\hline & \begin{tabular}{l|l|}
5 & Obat-obatan \\
\end{tabular} & $250.390 .000,00$ & $45.250 .000,00$ & $50.300 .000,00$ \\
\hline & \begin{tabular}{l|l}
6 & Jamkesda,jamkesmas, askes \\
\end{tabular} & $60.097 .940,00$ & $30.275 .000,00$ & $55.270 .000,00$ \\
\hline & \begin{tabular}{l|l}
7 & Laboratorim \\
\end{tabular} & 150.000 .000 .00 & $85.500 .000,00$ & $100,000.000,00$ \\
\hline & 8 Radiologi & $100.000 .000,00$ & $55.500 .000,00$ & $45.175 .000,00$ \\
\hline & 9 Ambulance & $35.000 .000,00$ & $7.008 .000,00$ & $20.600 .000,00$ \\
\hline & 10 Jasa Konsultasi medic & $20.600 .060,00$ & $10.600 .000,00$ & $20.450 .000,00$ \\
\hline & \begin{tabular}{|l|l|}
11 & Jasa Konsultasi Gizi \\
\end{tabular} & $12.500,000,00$ & $7.500 .000,00$ & $11.500 .000,00$ \\
\hline & \begin{tabular}{|l|l|}
13 & Pemerksaan Kesehatan \\
\end{tabular} & $200.520 .000,00$ & $75.220 .000,00$ & $15.500 .000,00$ \\
\hline & \begin{tabular}{|l|l|}
14 & Pemelharaan Jenazah \\
\end{tabular} & $50,000,000,00$ & $25.500,000,00$ & $10.000 .000,00$ \\
\hline & \begin{tabular}{|l|l|}
15 & Pelayanan kerja sama phak ketiga \\
\end{tabular} & $72.140 .000,00$ & $21.155 .000,00$ & $33.000 .000,00$ \\
\hline & \begin{tabular}{|l|l|}
16 & Pendapatan lain-lain \\
\end{tabular} & $55.460 .000,00$ & $30,500,000,00$ & $50,205.000,00$ \\
\hline & Jumlah Pendapatan Jasa Layanan & $1.350 .508 .000,00$ & $578.008 .000,00$ & $672.500 .000,00$ \\
\hline II & Hibah & & & \\
\hline III & Pendapatas Hasil Kerja Sama & $150.000 .000,00$ & $100,000,000,00$ & $150,000.000,00$ \\
\hline IV & APBD & $100.000 .000,00$ & $100,000,000,00$ & $100,000,000,00$ \\
\hline$r$ & APBN & & 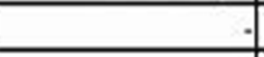 & 2. \\
\hline II & Lain-lain Pendapatan BLUD & & & \\
\hline III & Jumlah Pendapatan BLUD & $1.627 .508 .000,00$ & $678.008 .000,00$ & $922.500 .000,00$ \\
\hline
\end{tabular}

Sumber: RSUD Sele Be Solu Kota Sorong 


\subsection{Analisis Data}

Dari hasil penerimaan dana anggaran tahun 2015-2016 di atas selanjutnya penulis akan menganalisis penggunaan realisasi dana anggaran berdasarkan buku pedoman teknis pengelolaan keuangan badan layanan umum daerah menurut pemendagri no 61 tahun 2007

\subsubsection{Analisis Laporan Penggunaan Anggaran}

Laporan Penerimaan anggaran badan layanan umum daerah rumah sakit sele be solu pada umumnya sudah berjalan sesuai dengan sistem keakuntansiannya yakni berdasarkan pemendagri no 61 tahun 2007 tentang teknis pengelolaan keuangan badan layanan umum daerah atau pada rencana bisnis anggaran/RBA, hanya saja pada format laporan dari penerimaan yang berbeda karena ada penambahan akunt yakni APBD dan Hibah terikat

Penerimaan pendapatan APBD Rp. 100.000.000,00

Sedangkan pada Laporan Realisasi penggunaan Anggaran tidak ada aktifitas pembiayaan dari APBD tersebut.

Berikut fungsi dari APBD itu sendiri menurut buku panduan pengeloaan keuangan BLUD, Fleksibilitas pengeluaran biaya BLUD sebagaimana dimaksud pada ayat (1), hanya berlakuuntuk biaya BLUD yang berasal dari pendapatan selain dari APBN/APBD dan hibah terikat.

Dari penjelasan di atas sangat jelas bahwa pada table 4.3 Laporan realisasi anggaran sudah berjalan sesuai dengan penetapannya, yakni tidak ada aktifitas keakuntansian dari APBD ataupun Hibah terikat Selanjutnya untuk mengetahui perbedaan antara kedua dan untuk menghitung sisa dana dari tabel perbandingan sebelum dan sesudah di analisa yakni pada tabel 4.2 dan tabel 4.3 dari kedua tabel tersebut antara lain

( Triwulan Pertama + Triwulan Kedua Anggaran dalam DPA)

Tabel 4.2 (Sebelum di analisa)

$(678.008 .000,00+922.500 .000,00-$

1.627.508.000,00 )

$=(27.000 .000,000,00)$

Tabel 4.3( Sesudah di analisa )

$(678.008 .000,00+822.500 .000,00$ -

1.500.508.000,00 )

$=-$

Sisa dana anggaran dari tabel 4.2 tersebut di atas akan di simpan dan di anggarkan pada rencana bisnis anggaran berikutnya sebagai penerimaan dana BLUD

Berikut merupakan tabel pembenahi dari Rincian anggaran pendapatan RSUD Sele Be Solu Kota Sorong

Tabel 4.3

Rincian Anggaran Penerimaan Pendapatan RSUD Sele Be Solu KotaSorong Tahun 2016

\begin{tabular}{|c|c|c|c|c|c|c|}
\hline No & TRALAN & $\begin{array}{c}\text { ANGGARAN DALAM } \\
\text { DPA }\end{array}$ & $\begin{array}{l}\text { REALISASIS/D } \\
\text { TRWVLLAN LALU }\end{array}$ & $\begin{array}{c}\text { REALISASI } \\
\text { TRIVTLAN INI }\end{array}$ & $\begin{array}{l}\text { REALISASIS/D } \\
\text { IRIVULAN IN }\end{array}$ & $\begin{array}{c}\text { LEBIH } \\
\text { (KURANG) }\end{array}$ \\
\hline 1 & 2 & 3 & 4 & 5 & $6=(4+5)$ & $7=(3-6)$ \\
\hline \multirow[t]{17}{*}{1} & Jasa Layanan & & & & & \\
\hline & \begin{tabular}{|l|l|}
1 & Administrasi Pendaftaran \\
\end{tabular} & 70.000 .000 .00 & $45.000 .000,00$ & $600.000 .000,00$ & $105.000,000,00$ & $(35.000,000,00$ \\
\hline & \begin{tabular}{l|l|}
2 & Tindakan Operasi \\
\end{tabular} & $100.500 .000,00$ & $63.500 .000,00$ & $35.000 .000,00$ & 98.500 .000 .00 & 2.000 .000 .00 \\
\hline & \begin{tabular}{l|l|}
3 & Rawat Jalan \\
\end{tabular} & $30.300,000,00$ & $25.300 .000,00$ & $15.500 .000,00$ & $41.000 .000,00$ & 9.300 .000 .00 \\
\hline & + Raxat Inap unum & $150,000,000,00$ & $50.000 .000,00$ & $150.000 .000,00$ & $200.000,000,00$ & $(50.000,000,00$ \\
\hline & \begin{tabular}{l|l}
5 & Obat-obatan \\
\end{tabular} & $250.390 .000,00$ & $45.250 .000,00$ & $50.300 .000,00$ & 95.550 .000 .00 & $154,840,000,00$ \\
\hline & \begin{tabular}{c||c|}
6 & Jamkesda,jamkesmas,askes \\
\end{tabular} & $60.097 .940,00$ & $30.275 .000,00$ & $55.270 .000,00$ & $85.545 .000,00$ & 25.447 .060 .00 \\
\hline & \begin{tabular}{|l|l|}
7 & Laboratorium \\
\end{tabular} & $123,000,000,00$ & $85.500 .000,00$ & $100.000 .000,00$ & $185.300 .000,00$ & $(62.500 .000,00$ \\
\hline & \begin{tabular}{|c|c|} 
s & Radiologi \\
\end{tabular} & $100.000 .000,00$ & $55.500 .000,00$ & 45.175 .000 .00 & $100.675 .000,00$ & $(675.000 .00$ \\
\hline & \begin{tabular}{|l|l|}
9 & Ambulance \\
\end{tabular} & 35.000 .000 .00 & $7.008 .000,00$ & $20.600 .000,00$ & 27.608 .000 .00 & 7.392 .000 .00 \\
\hline & \begin{tabular}{|l|l|}
10 & Jasa Konsultasimedic \\
\end{tabular} & $20.600 .060,00$ & $10.600 .000,00$ & $20.430 .000,00$ & $31.050 .000,00$ & $(10.449 .940 .00$ \\
\hline & \begin{tabular}{|l|l|}
11 & Jasa Konsultasi Gizi \\
\end{tabular} & $12.500,000,00$ & $7.500,000,00$ & $11.500 .000,00$ & $19.000 .000,00$ & $(6.500 .000,00$ \\
\hline & \begin{tabular}{|l|l|}
13 & Pemeriksaan Kesehatan \\
\end{tabular} & $200,520,000,00$ & $75.220 .000,00$ & $15,500,000,00$ & $90.720 .000,00$ & $109.800 .000,00$ \\
\hline & \begin{tabular}{|l|l|}
14 & Pemeliharaan Jenazah \\
\end{tabular} & $50.000,000,00$ & $25.500,000,00$ & $10.000 .000,00$ & $35.500 .000,00$ & $14.500 .000,00$ \\
\hline & \begin{tabular}{|l|l|}
15 & Pelayanan kefja sama pihak ketiga \\
\end{tabular} & $72.140,000,00$ & $21.155,000,00$ & $33,000,000,00$ & $54.155 .000,00$ & $17.985 .000,00$ \\
\hline & \begin{tabular}{|l|l|}
16 & Pendapatan lainlain \\
\end{tabular} & $55,460,000,00$ & $30,500,000,00$ & $50.205,000,00$ & $80.705 .000,00$ & $(25.245 .000,00)$ \\
\hline & Jumlah Pendapatan Jasa Lavanan & $1.350 .508,000,00$ & $578.008 .000,00$ & $672,500.000,00$ & 1.250 .508 .000 .00 & $100.000 .000,00$ \\
\hline II & Pendapatan Hasil Kerja Sama & $150,000,000,00$ & $100.000 .000,00$ & $130.000 .000,00$ & 250.000 .000 .00 & $(100.000 .000,00)$ \\
\hline III & Lain-lain Pendapatan BLCD & & & & & - \\
\hline iv & Jumlah Pendapatan BLCD & $1.500 .508 .000,00$ & $678.008 .000,00$ & $822.500 .000,00$ & $1.500 .508 .000,00$ & - \\
\hline
\end{tabular}

Sinmmer. Data Olah 
Tabel 4.4

Laporan Realisasi Penggunaan Dana BLUD RSUD Sele Be Solu Kota Sorong Tahun 2016

\begin{tabular}{|c|c|c|c|c|c|c|c|}
\hline \multirow{2}{*}{ so } & \multirow{2}{*}{\multicolumn{2}{|c|}{ tRALAX }} & AYGGARAN & REALISASI S/D & REALISASI S/D & REALISASI S/D & LEBIA \\
\hline & & & DALAMI DPARBA & TRIVELAN LALEI & TRIVULANNT/II & TRIVULANNT & (KLRANG) \\
\hline $\begin{array}{l}1 \\
\end{array}$ & \multicolumn{2}{|c|}{ Penerimaan } & $1.600 .508 .000,00$ & & & & \\
\hline \begin{tabular}{l|l}
$B$ & $P$ \\
c & B \\
\end{tabular} & & geluaraan & & $678.008 .000,00$ & $922.500 .000,00$ & $1.600 .508 .000,00$ & $1,600,508,000,00$ \\
\hline & & Biaya Pelayanan & 963.730 .000 .00 & $382.930,000,00$ & $690,950.000,00$ & 1.073 .880 .000 .00 & $110,150,000,00$ \\
\hline & & \begin{tabular}{l|l} 
a & Belanja Pegawai \\
\end{tabular} & 350.920 .000 .00 & $120.200 .000,00$ & $200.000 .000,00$ & $320.200 .000,00$ & $(30.720 .000,00)$ \\
\hline & & \begin{tabular}{l|l|}
$\mathrm{b}$ & Biaya Bahan \\
\end{tabular} & $100.352 .000,00$ & $50.200 .000,00$ & $50.300 .000,00$ & $100.500 .000,00$ & $148.000,00$ \\
\hline+ & & \begin{tabular}{l|l} 
e & Biaya Barang dan Jasa \\
\end{tabular} & $70,000,000,00$ & $50,500,000,00$ & $50.650 .000,00$ & $101.150,000,00$ & $31,150,000,00$ \\
\hline \multirow[t]{2}{*}{ 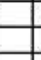 } & & \begin{tabular}{l|l}
$f$ & Biaya Depresiasi \\
\end{tabular} & -1 & - & 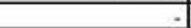 & & \\
\hline & & \begin{tabular}{l|l|} 
giaya Amortisasi \\
\end{tabular} & & - & - & & \\
\hline \multirow[t]{2}{*}{ 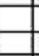 } & & \begin{tabular}{l|l} 
h & Biaya Pelayanaan lainnya \\
\end{tabular} & 42.458 .000 .00 & $30.440 .000,00$ & 40.000 .000 .00 & 70.440 .000 .00 & $27.982 .000,00$ \\
\hline & & & & & & & 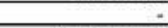 \\
\hline & \multirow{2}{*}{\begin{tabular}{l|l}
2 & B \\
& $a$
\end{tabular}} & Biaya Umum dan Admistrasi & $634.778 .000,00$ & $293.078 .000,00$ & $230.550 .000,00$ & $523.628 .000,00$ & $(111.150 .000,00)$ \\
\hline & & \begin{tabular}{l|l} 
a & Biaya Pegawai \\
\end{tabular} & $270.593 .000,00$ & $131.050 .000,00$ & $100.000 .000,00$ & 231.050 .000 .00 & $(39.543 .000,00)$ \\
\hline & & \begin{tabular}{l|l|} 
g & Biaya Amortisasi \\
\end{tabular} & & - & - & & \\
\hline & & I1 $\quad$ Biaya Umum dan Admistrasi Lainnya & $30.120 .000,00$ & - & $30.120 .000,00$ & & $(30.120 .000,00)$ \\
\hline D & & YA NOX OPERASIOXAL & 2.000 .000 .00 & 2.000 .000 .00 & 1.000 .000 .00 & $3.000 .000,00$ & 100000000 \\
\hline & & 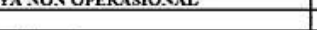 & $2.000 .000,000$ & & & & \\
\hline & 1 & Biaya Bunga & & & -1 & & \\
\hline & 2 & Biaya Administrasi Bank & $2.000 .000,00$ & $2.000 .000,00$ & $1.000 .000,00$ & $3.000 .000,00$ & $1.000 .000,00$ \\
\hline & 3 & Biaya Kerugian Penjualan Aset Tetap & -1 & - & -1 & & \\
\hline & 4 & Biaya Kerugian Penurunan Nilai & 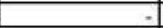 & - & 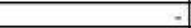 & & \\
\hline & 5 & Biaya Non Operasional Lainuya & $\Delta$ & $=$ & - & & \\
\hline & & & & & & & \\
\hline & & TUMILAH & $1.500 .508 .000,00$ & $678.008 .000,00$ & $822.500 .000,00$ & $1.500 .508 .000,00$ & \\
\hline
\end{tabular}

Sumber Data Olahan 
Tabel 4.5

\section{Buku Kas RBARumah Sakit} TAHUN Anggaran 2016

\begin{tabular}{|c|c|c|c|c|c|}
\hline \multirow{4}{*}{ No } & \multirow{4}{*}{$\begin{array}{c}\text { TAHUN } \\
\text { ANGGARAN }\end{array}$} & PENERIMAAN & RENCANA & & \\
\hline & & \multirow{2}{*}{ Rp. } & PENGELUARAAN & REALISASI & SALDO KAS \\
\hline & & & Rp. & Rp.. & RUMAH SAKIT \\
\hline & & (DEBET) & (KREDIT) & & \\
\hline 1 & 2016 & Anggaran BLUD & $1.600 .508 .000,00$ & & $1.600 .508 .000,00$ \\
\hline 2 & & (Pengg. Biaya Operasional) & & & \\
\hline 3 & & Biaya Pelayanan & $963.730 .000,00$ & $1.073 .880 .000,00$ & $526.628 .000,00$ \\
\hline 4 & & Biaya Atministrasi Umum & $634.778 .000,00$ & $523.628 .000,00$ & $3.000 .000,00$ \\
\hline 5 & & Pengg. Biaya Non Operasional & $2.000 .000,00$ & $3.000 .000,00$ & \\
\hline & & & & & \\
\hline
\end{tabular}

Sumber Data Olahan

Buku Kas ini disusun berdasarkan relisasi penggunaan Dana Badan Layanan Umum Daerah Rumah Sakit dari penerimaan maupun pengeluaran seperti dapat dilihat di atas Buku kas Rumah Sakit jumlah penerimaan dana BLUD Tahun 2016 sebesar Rp. 1.500.508.000,00,-dana ini akan di gunakan untuk pengeluaran pada biaya operasional yang terdiri dari biaya pelayanan sebesar Rp. 963.730.000,00,- dan realisasinya adalah Rp. 1.073.880.000,00 sehingga dapat disimpulkan tidak ada saldo kas akhir dari jumlah penerimaan dan jumlah realisasi pengeluaraan pada RBA-BLUD RSUD Sele Be Solu Kota Sorong tahun anggaran 2016.

\section{Penutup}

\subsection{Kesimpulan}

Kesimpulan yang penulis ambil adalah :

1. Penggunaan dana pada Rumah Sakit Umum Sele Be Solu Kota Sorong telah sesuai dengan sistem rencana bisnis anggaran/RBA yang ada pada peraturan pemndagri no 61 tahun 2007 tentang Pedoman Teknis Pengelolaan Keuangan Badan Layanan Umum Daerah Namun pencatatannya yang belum sesuai dengan standar akuntansi yang berlaku.

2. Kekurangan penepatan Arsip keuangan yang baik sehingga menimbulkan kesalahan pencatatan pada saat mempsoting surat perintah pencairan dana

3. Perlu ketelitian dalam melakukan pemeriksaan bukti-bukti surat perintah pencairan dana pada pos-pos yang menjadi sumber pendapatan dana BLUD pada satu kali rencana bisnis anggaran per triwulan

\subsection{Saran}

Dari kesimpulan di atas penulis dapat memberi saran pada Rumah sakit lebih khusus pada instansi-instansi yang bertanggung jawab terhadap Anggaran BLUD Rumah Sakit adalah sebagai berikut :

1. Pencatatan dalam Perencanaan Anggaran Badan Layanan Umum Daerah harus sesuai dengan standar akuntansi yang berlaku dalam hal ini pada pedoman teknis pengelolaan keuangan dalam peraturan menteri dalam negeri no 61 tahun2007 antara lain :

a. Memmposting transaksi sebaiknya sesuai dengan rencana bisnis anggaran yang telah ada pada sistem pengelolaan anggaran blud Tidak menambah lebihkan jumlah format kolom pada table anggaran sehingga tidak membingungkan saat memposting atau mengisi data laporan keuanagan.

b. Pegawai yang telah di tetapkan dalam tugas penanganan anggaran blud atau pegawai blud sebaiknya mempunyai pengarsipan data keuangan pada setiap Ruangan maupun instansi-instansi yang menjadi sumber dari penerimaan pendapatan blud, sehingga pada akhir pembuatan laporan keuangan sudah mempuyai data yang lengkap.

c. Dalam satu kali rencana bisnis anggaran harus di lakukakan sesuai dengan waktu yang ditentukan dan tidak penundaan waktu guna mengantisipasi hal-hal yang tidak ingingkan seperti kekurangan obatobatan, kekurangan barang habis pakai pada rumah sakit guna memuaskanhati pada setiap konsumen yang ada.

\section{DAFTAR PUSTAKA}

Buku panduan Badan Layanan Umum Daerah

Ibrahim Abdulah (1991). KamusAkuntansi. Jakarta Timur: PT. Mario Grafika.

M.Suparmoko (2000). Keuangan Negara. Edisi 5.Yogyakarta: BPFE-Yogyakarta. 
Pemendagri no 61 Tahun 2007 Teknis Pengelolaan Keuangan Badan Layanan Umum Daerah.

Pemendagri no 61 Tahun 2007 Ibid

Rudianto.(2012) .Pengantar Akuntansi. Jakarta: Erlangga.

Rachmat (2010). AkuntansiPemerintahan. Bandung: CV PustakaSetia.

V. Wiratnasujarweni (2015). Akuntansi sector public.Yogyakarta:Pustakabaru press. 